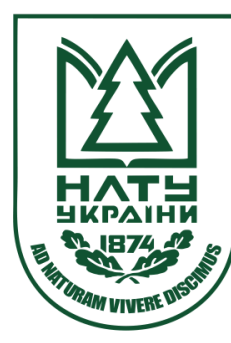

Науковий вісник НлТУ України

Scientific Bulletin of UNFU

http://nv.nltu.edu.ua

https://doi.org/10.15421/40280419

$@ \bowtie$ Correspondence author

Article received 13.04.2018 p.

Article accepted 26.04.2018 p.

O. P. Savitska

УДК 330.131.7:338.48 (477)

Sawicka@bigmir.net

О. П. Савіцька, Н. В. Савіцька

Львівський інститут економіки і туризму, м. Львів, Украйна

\title{
ОЦІНЮВАННЯ РІВНЯ РИЗИКУ ТУРИСТИЧНОЇ ДІЯЛЬНОСТІ РЕГІОНІВ УКРАЇНИ СТАТИСТИЧНИМИ МЕТОДАМИ
}

Незважаючи на значну кількість публікацій з тематики управління ризиками у сфері туристичної діяльності, порівняльний аналіз наукових праць вітчизняних і зарубіжних науковців показав потреба подальшого вивчення ризиків у сфері туристичної діяльності на регіональному рівні, для врахування загроз і небезпек під час формування пріоритетних напрямів розвитку регіонів, формування стратегій регіонального розвитку, посилення конкурентоспроможності та іміджу як регіонів, так і країни загалом та вихід на нові міжнародні ринки послуг тощо. Аналіз показників діяльності суб'єктів туристичної діяльності України дав змогу виявити негативні тенденції протягом 2013-2015 рр. у їхньому розвитку, що свідчить про неспроможність туристичних підприємств своєчасно реагувати на вплив чинників внутрішнього та зовнішнього середовища. Оцінено рівень та проаналізовано ризики туристичної діяльності регіонів України статистичним методом шляхом розрахунку таких показників, як середнє значення, дисперсія, середньоквадратичне відхилення, коефіцієнт варіації. Проранжовано регіони України за значенням коефіцієнтів варіації доходу від надання туристичних послуг, витрат суб'єктів туристичної діяльності на послуги сторонніх організацій та завантаженості суб'єктів туристичної діяльності.

Ключові слова: туризм; суб'єкти туристичної діяльності; ризик; статистичний метод оцінювання ризиків; середнє значення; дисперсія; середньоквадратичне відхилення; коефіцієнт варіації; ранжування регіонів.

Вступ. Динамічні процеси у розвитку світової економіки у поєднанні із реформуванням економічних відносин надають господарському комплексу України дедалі більше ринкових рис і гвносять у туристичну діяльність додаткові елементи невизначеності та ризику. Дослідження ризику набули особливої актуальності у туристичній діяльності, функціонування якої тісно пов'язане з прийняттям рішень в умовах мінливого суспільного середовища (Felenchak, 2012).

Методи дослідження. Під час дослідження використано загальнонаукові та спеціальні методи, зокрема: методи теоретичного узагальнення, порівняльного аналізу наукових праць вітчизняних та зарубіжних науковців; статистичні методи - для розрахунку показників рівня ризиків туристичної діяльності регіонів України (середнє значення, дисперсія, середньоквадратичне відхилення, коефіцієнт варіації); метод ранжування - для визначення позицій регіонів у рейтингу за рівнем ризику туристичної діяльності.

Аналіз останніх досліджень і публікацій. У наукових джерелах можна знайти досить багато досліджень щодо управління ризиками. Варто відзначити значний внесок у розвиток науки ризикології таких зарубіжних та вітчизняних вчених-науковців, як О. Беднарська (2011, 2013), Г. Великоіваненко (2004), В. Вітлінський (2004), О. Кузьмін (2011), Н. Михайлова (2011), Н. Подольчак (2011), В. Харчук (2011), Д. Вілфорд (1995), Н.
Догерті (2000), М. Дорфман (2007), К. Сміт (1995), К. Смітсон (1995), Б. Фісчгофф (2013), Б. Фливберг (2003). Чимало науковців вивчали питання ефективного управління ризиками у сфері туристичної діяльності. Зокрема, висвітлено аспекти трактування поняття "ризик" у туристичній сфері (Bohdan \& Sukhorukova, 2016), проблеми вибору та застосування ефективних методів оцінювання та аналізування ризиків у туризмі (Bohdan \& Vorobiova, 2017; Chernyshev, Shynkarenko \& Shynkarenko, 2017), особливості формування системи управління ризиками в туризмі (Hnylianska \& Toporovskyi, 2012) тощо. Дослідження прояву ризику у певних сферах туристичної діяльності здійснено у роботах таких учених: О. Михайлюк (2014) проаналізувала екологічні ризики, які можуть гальмувати розвиток сільського (зеленого) туризму; Т. Скоробогатова (2012) систематизувала ризики у сервісній логістиці та виділила специфіку їх прояву у сфері туризму. Н. Донєва (2014) розробила методику кількісної оцінки ризиків під час вибору туристичних подорожей на основі формалізованої моделі характеристик послуг, платіжної матриці та матриці ризиків, яка дає змогу визначити пріоритетність запропонованого туристичного продукту. Питання ризик-контролю прийняття рішень щодо обсягу формування туристичних продуктів відображено у праці А. Денисенко (Denysenko, 2014).

Інформація про авторів:

Савіцька Ольга Петрівна, канд. екон. наук, доцент, завідувач кафедри менеджменту та комерційної діяльності.

Email: Sawicka@bigmir.net

Савіцька Наталія Володимирівна, канд. екон. наук, доцент, кафедра міжнародної економіки та інвестиційної діяльності, в.о. декана бухгалтерсько-економічного факультету. Email: Sawicka@bigmir.net

Цитування за ДСтУ: Савіцька О. П., Савіцька Н. В. Оцінювання рівня ризику туристичної діяльності регіонів України статистичними методами. Науковий вісник НЛтУ України. Серія Економічна. 2018, т. 28, № 4. С. 102-107

Citation APA: Savitska, O. P., \& Savitska, N. V. (2018). Risk Level Assessment of Tourist Activity of Regions in Ukraine by Statistical Methodi. Scientific Bulletin of UNFU, 28(4), 102-107. https://doi.org/10.15421/40280419

102 Науковий вісник НЛтУ України, 2018, т. 28, № 4 Scientific Bulletin of UNFU, 2018, vol. 28, no 4 
У науковій літературі ризики туристичної діяльності досліджують на чотирьох рівнях такі вчені-науковці:

- на рівні туристичного підприємства - П. Гудзь (Gudz, 2015), Д. Головко (Holovko, 2015), В. Карцева (Kartseva, 2016), К. Копачова (Kopachova, 2013), А. Мельникова (Melnikova, 2016), Н. Михайлова (Mykhailova, 2016);

- на рівні регіонів України - М. Грицюк (Grytsiuk, 2017), Ю. Грицюк (Grytsyuk, 2017, 2018), О. Михайлюк (Mykhailiuk, 2014), Л. Шпак (Shpak, 2014);

- на державному рівні - Т. Малишева (Malysheva, 2015), I. Писаревський (Pysarevskyi, 2015), I. Полчанінова (Polchaninova, 2015), Г. Солодовник (Solodovnyk, 2014), А. Чудаколов (Chudakolov, 2014);

- на міжнародному рівні - О. Беднарська (Bednarska, 2013), О. Гук (Huk, 2011), О. Кузьмін (Kuzmin, 2011), I. Кулиняк (Kulyniak, 2013), Н. Подольчак (Podolchak, 2011), А. Харчук (Kharchuk, 2011).

Однак, враховуючи економічну та політичну нестабільність в Україні, посилення євроінтеграційних процесів на фоні обмежень зовнішньоекономічних відносин 3 Російською Федерацією, тимчасову окупацію АР Крим, збільшення ролі сфери послуг тощо, доцільно більше уваги приділити вивченню ризиків у сфері туристичної діяльності на регіональному рівні, для врахування загроз і небезпек під час формування пріоритетних напрямів розвитку регіонів, формування стратегій регіонального розвитку, посилення конкурентоспроможності та іміджу як регіонів, так і країни загалом та вихід на нові міжнародні ринки послуг тощо.

Формулювання мети дослідження. Мета роботи полягає в оцінюванні та аналізуванні рівня ризику туристичної діяльності регіонів України статистичним методом.

Викладення основного матеріалу дослідження. Події, які відбулись в Україні впродовж 2013-2014 pp., призвели до зниження фінансової стабільності багатьох суб'єктів туристичної діяльності, зокрема, протягом 2014-2015 рр. спостерігалось зменшення доходу від надання туристичних послуг на фоні зростання витрат на послуги сторонніх організацій, i, як наслідок, у 2015 p. витрати перевищили доходи. У 2016 р. спостерігається зростання доходів порівняно з попереднім періодом на $138 \%$, але і витрати також зростають (на $33 \%$ ) (рис. 1).

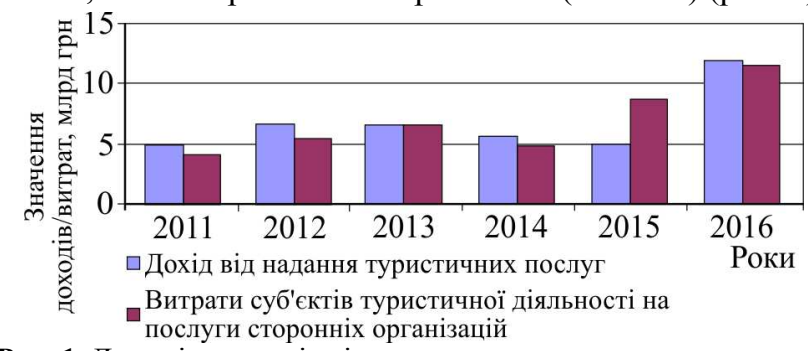

Рис. 1. Динаміка доходів від надання туристичних послуг та витрат суб'єктів туристичної діяльності на послуги сторонніх організацій (побудовано за даними Держстату України. www.ukrstat.gov.ua)

Аналогічно за період 2013-2015 рр. зазнали падіння такі показники, як кількість туристів, обслугованих суб'єктами туристичної діяльності, та кількість суб'єктів туристичної діяльності. Хоча у 2016 р. спостерігається незначний ріст цих показників (рис. 2, 3).

Окрім цього, впродовж 2013-2015 рр. темпи зростання витрат туроператорів перевищували темпи зростання кількості та вартості реалізованих кінцевому споживачеві туристичних продуктів. Ці тенденції свідчать про неспроможність туристичних операторів, як і тура- гентів, своєчасно пристосуватися до швидких змін середовища їх функціонування. Як наслідок, виникає потреба впровадження у систему менеджменту якісно нового інструментарію, що забезпечить своєчасне реагування на ризики (Melnikova, 2016).

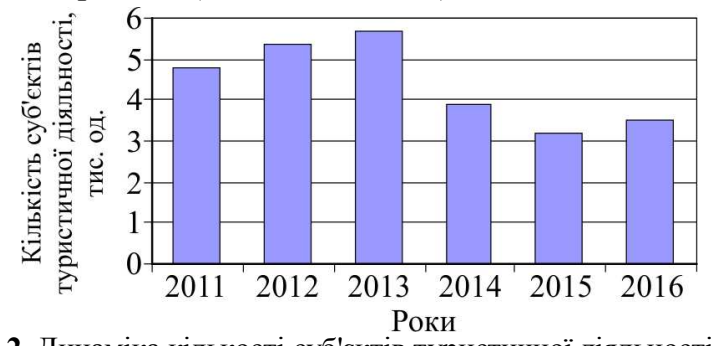

Рис. 2. Динаміка кількості суб'єктів туристичної діяльності

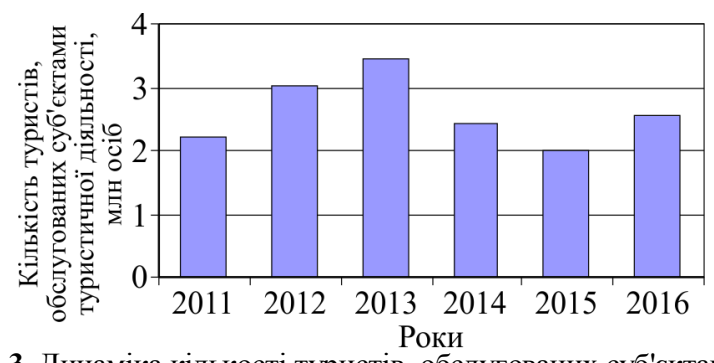

Рис. 3. Динаміка кількості туристів, обслугованих суб'єктами туристичної діяльності (побудовано за даними Держстату України, www.ukrstat.gov.ua).

У теорії сучасного ризик-менеджменту використовують статистичні й аналітичні методи кількісної оцінки ризику. До аналітичних методів належать: метод сценаріїв, дерево рішень, метод аналізу імовірнісних розподілів, метод Монте-Карло, метод достовірності еквівалентів. Сутність статистичних методів зводиться до визначення ймовірності виникнення втрат на основі статистичних даних попереднього періоду. В абсолютному вираженні найчастіше як величину ступеня ризику використовують міру розсіювання значень результативного показника відносно центру групування. Перевагою статистичного методу є розвинений математичний інструментарій, недоліком - труднощі зі збором та обробленням якісної інформації, а також в оцінюванні унікальних об'єктів; також малоінформативними є результати дослідження об'єктів 3 незначним терміном функціонування. Незважаючи на зазначений недолік, статистичний метод залишається одним із найприйнятніших, зрозумілих широкому загалу, методів власне кількісної оцінки ризику (Koval, 2014).

Система показників статистичного методу оцінювання ризику оперує такими показниками: середнє значення, дисперсія, середньоквадратичне відхилення, коефіцієнт варіації та ін. Зазначені показники розраховують за такими формулами:

1. $D(x)$ - дисперсія - середньозважене із квадратів відхилень дійсних результатів від середніх очікуваних. Характеризує розсіювання значення випадкового параметра від його середнього прогнозованого значення, розраховують за формулою

$$
D(x)=\frac{1}{n} \sum_{i=1}^{n}\left(x_{i}-M(x)\right)^{2},
$$

2. $\delta(x)$ - середньоквадратичне відхилення показує максимально можливе коливання певного параметра від його середньоочікуваної величини та дає змогу оцінити ступінь ризику 3 погляду ймовірності його здійснення (чим більша величина цієї числової характеристики, тим ризикованішим є рішення): 


$$
\delta(x)=\sqrt{D(x)} .
$$

3. $K(x)_{V A R}-$ коефіцієнт варіації порівнює ризикованість напрямів діяльності і конкретних ситуацій за ознаками (втратами), вираженими у різних одиницях виміру:

$$
K(x)_{V A R}=\delta(x) / M(x) .
$$

де: $x_{i}$ - значення $i$-тої величини; $M(x)$ - середнє значення величин; $n$ - кількість аналізованих величин.

Коефіцієнт варіації може змінюватися в межах від 0 до 1. Чим менша величина, тим стабільнішою $є$ прогнозована ситуація і відповідно менший ступінь ризику здійснення напряму діяльності чи певного заходу.

У літературі подають таку інтерпретацію значень коефіцієнта варіації: 0-0,1 - мінімальний ризик; 0,1-0,25 малий ризик; 0,25-0,5 - допустимий ризик; 0,5-0,75критичний ризик; 0,75 і більше - катастрофічний ризик.

Сутність поняття "ризик" у туристичній діяльності науковці (Vitlinskyi \& Velykoivanenko, 2004; Mykhailova \& Kartseva, 2016; Bohdan \& Sukhorukova, 2016) пропонують розглядати у трьох основних аспектах:

1) ймовірність (загроза) втрати туристичним підприємством ресурсів, недоотримання доходів (прибутків) або появи додаткових витрат;

2) можливість відхилення від передбачуваної мети;

3) загроза несприятливого результату та невизначеність, яка пов'язана з якою-небудь подією чи ії наслідком.

Отже, розрахунок рівня ризикованості туристичної діяльності регіонів України проведемо за допомогою статистичного методу оцінювання ризиків. Враховуючи подані вище трактування поняття "ризику", для розрахунків обрали найбільш релевантні дані, які відображатимуть ризикованість туризму в регіонах, а саме:

• дохід від надання туристичних послуг (без ПДВ, акцизів і аналогічних обов'язкових платежів);

• витрати суб'єктів туристичної діяльності на послуги сторонніх організацій, що використовуються у виробництві туристичного продукту;

Табл. 1. Оцінювання рівня ризику туристичної діяльності статистичним методом та ранжування регіонів України

\begin{tabular}{|c|c|c|c|c|c|c|c|c|c|c|c|}
\hline \multirow{2}{*}{ Регіон } & \multicolumn{5}{|c|}{$\begin{array}{c}\text { Відхилення доходу від надання } \\
\text { туристичних послуг }\end{array}$} & \multirow{2}{*}{$\begin{array}{c}\text { Середнє } \\
\text { значення }\end{array}$} & \multirow{2}{*}{ Дисперсія } & \multirow{2}{*}{$\begin{array}{c}\text { Середньо- } \\
\text { квадратичне } \\
\text { відхилення }\end{array}$} & \multirow{2}{*}{$\begin{array}{c}\text { Коефіцієнт } \\
\text { варіації }\end{array}$} & \multirow{2}{*}{ Рівень ризику } & \multirow{2}{*}{$\begin{array}{c}\text { Ранг } \\
\text { регіону }\end{array}$} \\
\hline & $\begin{array}{l}2012 / \\
2011\end{array}$ & $\begin{array}{l}2013 / \\
2012\end{array}$ & $\begin{array}{l}2014 / \\
2013\end{array}$ & $\begin{array}{l}2015 / \\
2014\end{array}$ & $\begin{array}{l}2016 / \\
2015\end{array}$ & & & & & & \\
\hline Україна & 1,35 & 0,98 & 0,86 & 0,90 & 2,38 & 1,29 & 0,33 & 0,57 & 0,44 & допустимий & \\
\hline Чернігівська & 1,38 & 1,15 & 1,13 & 1,29 & 1,29 & 1,25 & 0,01 & 0,10 & 0,08 & мінімальний & 1 \\
\hline Дніпропетровська & 1,07 & 1,08 & 0,82 & 1,11 & 1,16 & 1,05 & 0,01 & 0,12 & 0,11 & малий & 2 \\
\hline Хмельницька & 1,12 & 1,02 & 1,11 & 0,82 & 1,18 & 1,05 & 0,02 & 0,13 & 0,12 & малий & 3 \\
\hline Черкаська & 1,23 & 0,86 & 0,94 & 1,23 & 1,03 & 1,06 & 0,02 & 0,15 & 0,14 & малий & 4 \\
\hline Івано-Франківська & 1,06 & 1,04 & 0,85 & 1,27 & 1,30 & 1,10 & 0,03 & 0,17 & 0,15 & малий & 5 \\
\hline Кіровоградська & 0,69 & 1,14 & 0,84 & 0,75 & 0,82 & 0,85 & 0,02 & 0,15 & 0,18 & малий & 6 \\
\hline Тернопільська & 1,08 & 0,81 & 0,91 & 1,37 & 1,01 & 1,04 & 0,04 & 0,19 & 0,19 & малий & 7 \\
\hline Волинська & 1,13 & 1,18 & 0,73 & 1,49 & 1,29 & 1,16 & 0,06 & 0,25 & 0,21 & малий & 8 \\
\hline Одеська & 1,22 & 1,01 & 0,91 & 1,63 & 1,26 & 1,21 & 0,06 & 0,25 & 0,21 & малий & 9 \\
\hline Житомирська & 0,89 & 1,18 & 0,81 & 1,14 & 1,51 & 1,11 & 0,06 & 0,24 & 0,22 & малий & 10 \\
\hline Запорізька & 1,05 & 1,20 & 0,70 & 0,93 & 1,43 & 1,06 & 0,06 & 0,24 & 0,23 & малий & 11 \\
\hline Львівська & 1,55 & 1,29 & 0,76 & 1,08 & 1,45 & 1,23 & 0,08 & 0,28 & 0,23 & малий & 12 \\
\hline Полтавська & 1,31 & 0,95 & 0,75 & 0,91 & 1,46 & 1,07 & 0,07 & 0,26 & 0,25 & малий & 13 \\
\hline Рівненська & 1,43 & 0,66 & 1,13 & 1,44 & 1,13 & 1,16 & 0,08 & 0,29 & 0,25 & малий & 14 \\
\hline Закарпатська & 1,38 & 0,60 & 0,95 & 1,00 & 1,40 & 1,06 & 0,09 & 0,30 & 0,28 & допустимий & 15 \\
\hline Харківська & 0,71 & 1,15 & 0,63 & 1,24 & 1,29 & 1,01 & 0,08 & 0,28 & 0,28 & допустимий & 16 \\
\hline Вінницька & 2,15 & 0,74 & 0,98 & 1,46 & 1,45 & 1,36 & 0,24 & 0,49 & 0,36 & допустимий & 17 \\
\hline Сумська & 0,71 & 1,84 & 0,84 & 1,03 & 1,82 & 1,25 & 0,24 & 0,49 & 0,39 & допустимий & 18 \\
\hline Чернівецька & 0,67 & 1,26 & 0,83 & 1,86 & 1,96 & 1,31 & 0,27 & 0,52 & 0,40 & допустимий & 19 \\
\hline Миколаївська & 0,94 & 1,01 & 0,15 & 1,01 & 1,46 & 0,91 & 0,18 & 0,42 & 0,46 & допустимий & 20 \\
\hline м. Київ & 1,50 & 0,98 & 1,03 & 0,83 & 2,61 & 1,39 & 0,42 & 0,65 & 0,47 & допустимий & 21 \\
\hline Луганська & 0,63 & 2,47 & 0,02 & 1,37 & 2,08 & 1,31 & 0,81 & 0,90 & 0,69 & критичний & 22 \\
\hline Київська & 0,36 & 3,16 & 0,37 & 1,54 & 1,97 & 1,48 & 1,11 & 1,05 & 0,71 & критичний & 23 \\
\hline Донецька & 0,76 & 0,39 & 0,18 & 2,48 & 4,37 & 1,64 & 2,52 & 1,59 & 0,97 & катастрофічний & 24 \\
\hline Херсонська & 0,51 & 0,46 & 1,28 & 5,72 & 1,86 & 1,97 & 3,80 & 1,95 & 0,99 & катастрофічний & 25 \\
\hline
\end{tabular}
за коефіцієнтом варіації доходу від надання туристичних послуг (без ПДВ, акцизів і аналогічних обов'язкових платежів)

Джерело: побудовано за даними Держстату України (www.ukrstat.gov.ua).
- завантаженість суб'єктів туристичної діяльності, яку пропонуємо визначати як відношення кількості туристів, обслугованих туроператорами та турагентами, до кількості суб'єктів туристичної діяльності України.

Перелічені вище дані надаються Державною службою статистики України у статистичному бюлетені "Туристична діяльність України" відповідно для двох груп суб'єктів туристичної діяльності: юридичних осіб та фізичних осіб-підприємців. Варто звернути увагу на те, що розрахунки проведено без урахування тимчасово окупованої території Автономної Республіки Крим та м. Севастополя. Інформацію щодо Донецької та Луганської областей використано за суб'єктами туристичної діяльності, що подали звітність до територіальних органів Держстату, а це може вплинути на значні відхилення розрахункових даних від фактичних зазначених регіонів. Як можливість відхилення від передбачуваної мети доходів, витрат та завантаженості суб'єктів туристичної діяльності приймемо відхилення значення цих показнидля доходів характеризує позитивне відхилення й означає перевищення значення показника у теперішньому періоді (році) порівняно з попереднім періодом (роком), а значення менше 1 - навпаки - негативне відхилення і означає перевищення значення показника у попередньому періоді (році) порівняно з теперішнім періодом (роком). У такому випадку, значення доходу у минулому періоді (році) буде виступати у ролі мети, яку регіону потрібно досягнути у теперішньому періоді (році), а відхилення у більшу чи меншу сторону буде характеризувати ризик. Аналогічна ситуація буде характерною і для завантаженості суб'єктів туристичної діяльності, а для витрат суб'єктів туристичної діяльності на послуги сторонніх організацій простежуватиметься протилежна ситуація. Проведемо розрахунок показників апарату статистичного методу на основі даних туристичної діяльності регіонів України та результати подамо у табл. 1-3. ків до попереднього періоду (року). Значення більше 1 
Табл. 2. Оцінювання рівня ризику туристичної діяльності статистичним методом та ранжування регіонів України за коефіцієнтом варіації витрат суб'єктів туристичної діяльності на послуги сторонніх організацій, що використовуються у виробництві туристичного продукту

\begin{tabular}{|c|c|c|c|c|c|c|c|c|c|c|c|}
\hline \multirow[t]{2}{*}{ Регіон } & \multicolumn{5}{|c|}{$\begin{array}{c}\text { Відхилення витрат суб'єктів турис- } \\
\text { тичної діяльності на послуги сторон- } \\
\text { ніх організацій }\end{array}$} & \multirow{2}{*}{$\begin{array}{c}\text { Середнє } \\
\text { значення }\end{array}$} & \multirow[t]{2}{*}{ Дисперсія } & \multirow{2}{*}{$\begin{array}{c}\text { Середньо- } \\
\text { квадратичне } \\
\text { відхилення }\end{array}$} & \multirow{2}{*}{$\begin{array}{c}\text { Коефіцієнт } \\
\text { варіації }\end{array}$} & \multirow[t]{2}{*}{ Рівень ризику } & \multirow{2}{*}{$\begin{array}{c}\text { Ранг } \\
\text { регіону }\end{array}$} \\
\hline & \begin{tabular}{|l|}
$2012 /$ \\
2011
\end{tabular} & \begin{tabular}{|l|}
$2013 /$ \\
2012
\end{tabular} & $\begin{array}{l}2014 / \\
2013\end{array}$ & $\begin{array}{l}2015 / \\
2014\end{array}$ & $\begin{array}{l}2016 / \\
2015\end{array}$ & & & & & & \\
\hline Україна & 1,31 & 1,21 & 0,72 & 1,81 & 1,33 & 1,28 & 0,12 & 0,35 & 0,27 & допустимий & \\
\hline Херсонська & 1,04 & 1,20 & 1,01 & 0,99 & 1,22 & 1,09 & 0,01 & 0,10 & 0,09 & мінімальний & 1 \\
\hline Волинська & 2,39 & 1,05 & 1,94 & 2,00 & 2,04 & 1,89 & 0,20 & 0,44 & 0,24 & малий & 2 \\
\hline Івано-Франківська & 1,23 & 0,73 & 0,75 & 1,11 & 1,38 & 1,04 & 0,07 & 0,26 & 0,25 & малий & 3 \\
\hline Одеська & 1,01 & 0,59 & 0,64 & 1,14 & 0,86 & 0,85 & 0,04 & 0,21 & 0,25 & малий & 4 \\
\hline м. Київ & 1,49 & 1,33 & 0,81 & 1,86 & 1,33 & 1,37 & 0,11 & 0,34 & 0,25 & малий & 5 \\
\hline Хмельницька & 1,36 & 1,14 & 0,58 & 1,22 & 1,50 & 1,16 & 0,10 & 0,32 & 0,27 & допустимий & 6 \\
\hline Закарпатська & 0,89 & 0,65 & 1,17 & 0,95 & 1,58 & 1,05 & 0,10 & 0,31 & 0,30 & допустимий & 7 \\
\hline Кіровоградська & 1,29 & 1,58 & 1,28 & 0,38 & 1,81 & 1,27 & 0,24 & 0,49 & 0,38 & допустимий & 8 \\
\hline Львівська & 0,87 & 1,54 & 0,42 & 1,54 & 1,42 & 1,16 & 0,20 & 0,44 & 0,38 & допустимий & 9 \\
\hline Вінницька & 1,22 & 1,14 & 0,69 & 1,57 & 2,56 & 1,44 & 0,39 & 0,63 & 0,44 & допустимий & 10 \\
\hline Харківська & 0,33 & 1,34 & 0,41 & 1,58 & 1,30 & 0,99 & 0,27 & 0,52 & 0,52 & критичний & 11 \\
\hline Тернопільська & 2,18 & 1,12 & 0,94 & 0,80 & 0,32 & 1,07 & 0,38 & 0,61 & 0,57 & критичний & 12 \\
\hline Запорізька & 2,16 & 0,55 & 0,39 & 0,97 & 1,57 & 1,13 & 0,43 & 0,66 & 0,58 & критичний & 13 \\
\hline Рівненська & 1,69 & 0,20 & 2,68 & 2,06 & 0,88 & 1,50 & 0,76 & 0,87 & 0,58 & критичний & 14 \\
\hline Дніпропетровська & 0,51 & 0,62 & 0,77 & 2,37 & 1,02 & 1,06 & 0,46 & 0,68 & 0,64 & критичний & 15 \\
\hline Київська & 1,04 & 2,50 & 0,18 & 0,91 & 0,67 & 1,06 & 0,61 & 0,78 & 0,74 & критичний & 16 \\
\hline Житомирська & 0,24 & 3,09 & 0,51 & 1,09 & 3,16 & 1,62 & 1,59 & 1,26 & 0,78 & катастрофічний & 17 \\
\hline Чернівецька & 0,14 & 1,03 & 1,39 & 4,62 & 1,71 & 1,78 & 2,30 & 1,52 & 0,85 & катастрофічний & 18 \\
\hline Черкаська & 6,43 & 1,37 & 0,78 & 1,61 & 1,23 & 2,28 & 4,37 & 2,09 & 0,92 & катастрофічний & 19 \\
\hline Полтавська & 0,94 & 6,47 & 0,72 & 1,07 & 1,14 & 2,07 & 4,87 & 2,21 & 1,07 & катастрофічний & 20 \\
\hline Донецька & 0,57 & 1,59 & 0,07 & 0,23 & 5,92 & 1,68 & 4,78 & 2,19 & 1,30 & катастрофічний & 21 \\
\hline Миколаївська & 0,10 & 0,43 & 0,17 & 11,69 & 0,90 & 2,66 & 20,45 & 4,52 & 1,70 & катастрофічний & 22 \\
\hline Чернігівська & 0,47 & 1,30 & 0,18 & 14,57 & 0,00 & 3,30 & 31,94 & 5,65 & 1,71 & катастрофічний & 23 \\
\hline
\end{tabular}

* - без врахування Луганської та Сумської областей, для яких відсугні дані у статистичному бюлетені (Побудовано за даними Держстату України, www.ukrstat.gov.ua).

Табл. 3. Оцінювання рівня ризику туристичної діяльності статистичним методом та ранжування регіонів України за коефіціснтом варіації завантаженості суб'єктів туристичної діяльності

\begin{tabular}{|c|c|c|c|c|c|c|c|c|c|c|c|}
\hline \multirow{2}{*}{ Регіон } & \multicolumn{5}{|c|}{$\begin{array}{c}\text { Відхилення завантаженості суб'єктів } \\
\text { туристичної діяльності }\end{array}$} & \multirow{2}{*}{$\begin{array}{c}\text { Середнє } \\
\text { значення }\end{array}$} & \multirow{2}{*}{ Дисперсія } & \multirow{2}{*}{$\begin{array}{l}\text { Середньо- } \\
\text { квадратичне } \\
\text { відхилення }\end{array}$} & \multirow{2}{*}{$\begin{array}{c}\text { Коефіцієнт } \\
\text { варіації }\end{array}$} & \multirow{2}{*}{ Рівень ризику } & \multirow{2}{*}{$\begin{array}{c}\text { Ранг ре- } \\
\text { гіону }\end{array}$} \\
\hline & $\begin{array}{l}2012 / \\
2011\end{array}$ & $\begin{array}{l}2013 / \\
2012\end{array}$ & \begin{tabular}{|l}
$2014 /$ \\
2013
\end{tabular} & $\begin{array}{l}2015 / \\
2014\end{array}$ & $\begin{array}{l}2016 / \\
2015\end{array}$ & & & & & & \\
\hline Україна & 1,22 & 1,08 & 1,03 & 1,02 & 1,15 & 1,10 & 0,01 & 0,08 & 0,07 & мінімальний & \\
\hline Тернопільська & 0,98 & 1,00 & 0,96 & 0,84 & 0,92 & 0,94 & 0,00 & 0,06 & 0,06 & мінімальний & 1 \\
\hline Дніпропетровська & 1,04 & 0,99 & 1,05 & 0,89 & 1,14 & 1,02 & 0,01 & 0,08 & 0,08 & мінімальний & 2 \\
\hline М. Київ & 1,24 & 1,22 & 0,95 & 1,10 & 1,15 & 1,13 & 0,01 & 0,10 & 0,09 & мінімальний & 3 \\
\hline Житомирська & 1,17 & 0,85 & 0,83 & 0,97 & 1,15 & 0,99 & 0,02 & 0,14 & 0,14 & малий & 4 \\
\hline Одеська & 0,77 & 0,90 & 0,85 & 1,07 & 1,18 & 0,96 & 0,02 & 0,15 & 0,15 & малий & 5 \\
\hline Херсонська & 0,62 & 1,05 & 0,97 & 0,98 & 1,04 & 0,93 & 0,03 & 0,16 & 0,17 & малий & 6 \\
\hline Рівненська & 1,09 & 0,84 & 0,75 & 0,87 & 1,21 & 0,95 & 0,03 & 0,17 & 0,18 & малий & 7 \\
\hline Вінницька & 0,89 & 1,31 & 0,77 & 1,20 & 1,12 & 1,06 & 0,04 & 0,20 & 0,19 & малий & 8 \\
\hline Миколаївська & 0,87 & 0,90 & 0,56 & 0,88 & 1,05 & 0,85 & 0,03 & 0,16 & 0,19 & малий & 9 \\
\hline Черкаська & 0,98 & 1,42 & 0,73 & 0,96 & 1,20 & 1,06 & 0,05 & 0,23 & 0,22 & малий & 10 \\
\hline Сумська & 1,41 & 0,88 & 0,73 & 0,85 & 1,08 & 0,99 & 0,06 & 0,24 & 0,24 & малий & 11 \\
\hline Волинська & 1,24 & 0,96 & 0,80 & 1,26 & 1,67 & 1,19 & 0,09 & 0,30 & 0,25 & малий & 12 \\
\hline Запорізька & 0,61 & 0,98 & 0,78 & 1,31 & 1,14 & 0,96 & 0,06 & 0,25 & 0,26 & допустимий & 13 \\
\hline Закарпатська & 1,06 & 1,56 & 0,65 & 1,01 & 1,12 & 1,08 & 0,09 & 0,29 & 0,27 & допустимий & 14 \\
\hline Кіровоградська & 0,61 & 0,65 & 0,71 & 1,12 & 1,11 & 0,84 & 0,05 & 0,23 & 0,27 & допустимий & 15 \\
\hline Харківська & 1,14 & 0,90 & 0,90 & 0,51 & 1,34 & 0,96 & 0,08 & 0,28 & 0,29 & допустимий & 16 \\
\hline Хмельницька & 0,80 & 0,74 & 0,93 & 1,44 & 0,69 & 0,92 & 0,07 & 0,27 & 0,30 & допустимий & 17 \\
\hline Львівська & 0,79 & 1,56 & 0,57 & 1,30 & 1,31 & 1,11 & 0,13 & 0,37 & 0,33 & допустимий & 18 \\
\hline Полтавська & 0,95 & 0,70 & 0,76 & 0,89 & 1,59 & 0,98 & 0,10 & 0,32 & 0,33 & допустимий & 19 \\
\hline Київська & 1,32 & 0,69 & 0,69 & 1,02 & 1,64 & 1,07 & 0,14 & 0,37 & 0,34 & допустимий & 20 \\
\hline Чернівецька & 0,44 & 1,15 & 1,59 & 0,99 & 1,22 & 1,08 & 0,14 & 0,37 & 0,35 & допустимий & 21 \\
\hline Івано-Франківська & 1,98 & 0,69 & 0,93 & 1,23 & 0,94 & 1,15 & 0,20 & 0,45 & 0,39 & допустимий & 22 \\
\hline Чернігівська & 0,86 & 0,59 & 0,84 & 0,95 & 1,79 & 1,01 & 0,17 & 0,41 & 0,41 & допустимий & 23 \\
\hline Луганська & 1,53 & 0,61 & 0,34 & 1,62 & 1,17 & 1,05 & 0,25 & 0,50 & 0,48 & допустимий & 24 \\
\hline Донецька & 1,35 & 1,09 & 0,55 & 0,81 & 2,30 & 1,22 & 0,36 & 0,60 & 0,49 & допустимий & 25 \\
\hline
\end{tabular}

Джерело: побудовано за даними Держстату України (www.ukrstat.gov.ua).

Розрахунок статистичним методом рівня ризикованості туристичної діяльності регіонів України шляхом розрахунку коефіцієнта варіації дав змогу виділити регіони за рівнем ризику та провести їх ранжування. Так, за коефіцієнтом варіації доходу від надання туристичних послуг (без ПДВ, акцизів і аналогічних обов'язкових платежів) найменш ризикованою виявились Чернігівська обл. з мінімальним рівнем ризику, а найбільш ризикованими є Донецька та Херсонська області з критичним рівнем ризику. За коефіцієнтом варіації витрат суб'єктів туристичної діяльності на послуги сторонніх організацій, що використовуються у виробництві туристичного продукту) найменш ризикованою $є$ Херсонська обл. з мінімальним рівнем ризику, а найбільш ризикованими є Житомирська, Чернівецька, Черкаська, Полтавська, Донецька, Миколаївська та Чернігівська 
області з критичним рівнем ризику. За коефіцієнтом варіації завантаженості суб'єктів туристичної діяльності мінімальний рівень ризику притаманний Києву, Тернопільській та Дніпропетровській областям, а найвищий рівень ризику характерний для Чернігівської, Донецької та Луганської областей. Загалом туристичний ринок України характеризується допустимим рівнем ризику, середнє значення коефіцієнта варіації за досліджуваними показниками не перевищує 0,5 .

Туристичні ризики поширюються не тільки на індустрію туризму, але й на суміжні галузі, а також на об'єкти інфраструктури і самих туристів, i, маючи мультиплікативний ефект, можуть досить істотно впливати на рівень туристичної активності. При цьому ризик несе не тільки ймовірність втрат, але і можливість отримання вигод від прийняття відповідних заходів, у чому проявляється стимуляційний фактор ризику (Bohdan \& Sukhorukova, 2016).

Висновки та перспективи подалыших досліджень. На результативність та ефективність туристичної діяльності регіону впливає комплекс внутрішніх і зовнішніх факторів, що призводить до втрат туристичним підприємством ресурсів, недоотримання доходів (прибутків) або появи додаткових витрат. Попереднє виявлення причин та наслідків можливих відхилень від передбачуваної мети дасть змогу вчасно відреагувати на негативні наслідки та розробити відповідні заходи протидії настанню загроз несприятливого результату та невизначеності, яка пов'язана 3 якою-небудь подією чи іiі наслідком.

Результати цього дослідження можуть бути корисними не тільки суб'єктам туристичної діяльності, а й місцевим та регіональним органам влади для формування планів розвитку у сфері туризму та вчасному реагуванні на високий рівень ризикованості для його нейтралізації, а також для інвесторів у виборі ефективних напрямів вкладення коштів.

У цьому дослідженні оцінювання та аналізування рівня ризикованості туристичної діяльності регіонів України проведено на основі значень одного 3 трьох показників, що досить однобоко відображає результати, не враховуючи при цьому багато інших факторів, які мають вплив на туристичну діяльність. У перспективі необхідно комплексно підходити до оцінювання рівня ризику, визначаючи його за системою багатьох показників, які синергетично впливають на загальний результат, який може істотно відрізнятись від отриманого у цій роботі.

\section{Перелік використаних джерел}

Bednarska, O. R., \& Kulyniak, I. Ya. (2013). Ryzyky u mizhnarodnomu turyzmi: faktory, klasyfikatsiia, metody optymizatsii. [Risks in international tourism: factors, classification, optimization methods]. Bulletin of Lviv Polytechnic National University: Series of Management and Entrepreneurship in Ukraine: the stages of formation and problems of development, 767, 3-8. [In Ukrainian].

Bohdan, N. M., \& Sukhorukova, O. P. (2016). Doslidzhennia ryzykiv u turyzmi. [Risks research in tourism]. Business Inform, 10, 206211. [In Ukrainian].

Bohdan, N. M., \& Vorobiova, S. O. (2017). Metody ta kryterii otsiniuvannia ryzykiv v turyzmi. [Methods and criteria for risk assessment in tourism]. Internauka, 15(2), 11-15. [In Ukrainian].

Chernyshev, V. H., Shynkarenko, V. M., \& Shynkarenko, L. V. (2017). Otsinka ryzykiv u turyzmi za dopomohoiu matematychnykh metodiv. [Risks assessment in tourism using mathema- tical methods]. Scientific Bulletin of Uzhgorod National University. Series: International Economic Relations and World Economy, 12(2), 177-181. [In Ukrainian].

Denysenko, A. (2014). Ryzyk-kontrol formuvannia turystychnoho produktu. [Risk control of tourist product formation]. Bulletin of the Kyiv National University of Technologies and Design, 4, 67-78. [In Ukrainian].

Doherty, N. A. (2000). Integrated Risk Management: Techniques and Strategies for Managing Corporate Risk. NewYork: McGraw-Hill.

Donieva, N. M. (2014). Kilkisna otsinka ryzykiv pry vybori turystychnoi podorozhi. [Quantitative risk assessment when choosing a tourist trip]. Economics: time realities, 2, 190-196. [In Ukrainian].

Dorfman, M. S. (2007). Introduction to Risk Management and Insurance (9 ed.). Englewood Cliffs, N. J: Prentice Hall.

Felenchak, Yu. (2012). Sotsialni ryzyky v turystychnii diialnosti: pidkhody do analizu ta otsiniuvannia. [Social risks in tourism activity: approaches to analysis and evaluation]. Visnyk of the Lviv University. Series: International Relations, 29(1), 213-220. [In Ukrainian].

Fischhoff, B. (2012). Risk Analysis and Human Behaviour. New York: Routledge.

Flyvbjerg, Bent (2003). Megaprojects and Risk: An Anatomy of Ambition. Cambridge University Press

Grytsyuk, M. Yu., \& Hrytsiuk, Yu. I. (2017). The risks analysis in projects management of sustainable tourism development in the Carpathian region of Ukraine. Scientific Bulletin of UNFU, 27(5), 164-174. https://doi.org/10.15421/40270532

Grytsyuk M. Yu., Hrytsiuk Yu. I. (2018). Natural Resource Management and Sustainable Development of Tourism in the Carpathian Region of Ukraine. Scientific Bulletin of UNFU, 28(2), 99-110. https://doi.org/10.15421/40280219

Gudz, P., \& Holovko, D. (2015). Vyiav ryzykiv v diialnosti turystychnoho pidpryiemstva. [Risk detection in the activities of a tourist enterprise]. Scientific Bulletin of the Odessa National Economic University, 10, 64-76. [In Ukrainian].

Hnylianska, L. I., \& Toporovskyi, V. Ya. (2012). Ryzyky v turystychnii diialnosti. [Risks in tourism activity]. Scientific Bulletin of UNFU, 22(12), 199-202. [In Ukrainian].

Kopachova, K. I. (2013). Upravlinnia ryzykom znyzhennia finansovoi stiikosti na turystskykh pidpryiemstvakh. [Risk Management for financial sustainability reduction in tourist enterprises]. Scientific Bulletin: Finances, Banks, Investments, 2, 151-157. [In Ukrainian].

Koval, L. P. (2014). Krytychnyi analiz metodychnykh pidkhodiv do kilkisnoi statystychnoi otsinky ryzykiv biudzhetu rehionu. [Critical analysis of methodical approaches to quantitative statistical estimation of regional budget risks]. Scientific Bulletin of Kherson State University. Series: Economic Sciences, 7(5), 20-24. [In Ukrainian].

Kuzmin, O. Ye., Podolchak, N. Yu., Bednarska, O. R., Kharchuk, V. Yu., \& Huk, O. V. (2011). Ryzyk-menedzhment u mizhnarodnii turystychnii diialnosti. [Risk management in international tourism activities]. Lviv: Rastr-7. [In Ukrainian].

Melnikova, A. V. (2016). Oblikovo-analitychne zabezpechennia upravlinnia ryzykamy diialnosti turystychnykh pidpryiemstv. [Accounting and analytical support for risk management of tourist enterprises]. Young Scientists Journal, 7, 95-100. [In Ukrainian].

Mykhailiuk, O. L. (2014). Ekolohichnyi ryzyk rozvytku silskoho (zelenoho) turyzmu v Odeskii oblasti. [Ecological risk of rural (green) tourism development in Odessa region]. Economic innovations, 58, 208-217. [In Ukrainian].

Mykhailova, N. V. (2011). Zahalni oznaky ta pryntsypy upravlinnia ryzykamy turystychnoi firmy. [General features and principles of travel company risk management]. Scientific Bulletin of Poltava University of Economics and Trade. A series of "Economic Sciences", 6(2), 222-226. [In Ukrainian].

Mykhailova, N. V., \& Kartseva, V. V. (2016). Klasyfikatsiia ryzykiv turystychnoho pidpryiemstva. [Classification of the tourist enterprise risks]. Scientific Bulletin of Poltava University of Economics and Trade. A series of "Economic Sciences", 3, 182-187. [In Ukrainian].

Pysarevskyi, I. M., Polchaninova, I. L., \& Malysheva, T. V. (2015). Otsinka ta prohnozuvannia zmin rynku turystskykh posluh v umovakh ryzyku: metodychnyi pidkhid. [Estimation and forecasting of 
changes in the tourist service market under risk: methodical approach]. Economic Space, 102, 83-93. [In Ukrainian].

Shpak, L. O. (2014). Osoblyvosti proiavu ta diahnostyka ryzykiv rehionalnykh turystychno-rekreatsiinykh kompleksiv. [Features of the manifestation and diagnostics of the risks of regional tourist and recreational complexes]. Investment: Practice and Experience, 4, 62-66. [In Ukrainian].

Skorobohatova, T. M. (2012). Ryzyky v servisnii lohistytsi: klasyfikatsiia, sutnist, spetsyfika proiavu u sferi turyzmu. [Risks in service logistics: classification, essence, specificity of manifestation in the tourism field]. Scientific Notes of Lviv University of Business and Law, 9, 93-97. [In Ukrainian].
Smith, C. Jr, Smithson, C., \& Wilford, D. S. (1995). Managing Financial Risk: A Guide to Derivative Products, Financial Engineering and Value Maximization. Chicago: Irwin Professional Publishing.

Solodovnyk, H. V., \& Chudakolov, A. Yu. (2014). Modeliuvannia ryzykiv u turystychnomu biznesi. [Risks modeling in the tourism business]. Scientific Bulletin of Construction, 2, 212-215. [In Ukrainian].

Turystychna diialnist. (n.d.). Turystychna diialnist $\mathrm{v}$ Ukraini: statystychnyi biuleten. [Tourist activity in Ukraine: statistical bulletin]. State Statistics Service of Ukraine. Retrieved from: http://www.ukrstat.gov.ua.

Vitlinskyi, V. V., \& Velykoivanenko, H. I. (2004). Ryzykolohiia v ekonomitsi ta pidpryiemnytstvi. [Riskology in Economics and Entrepreneurship]. Kyiv: KNEU. [In Ukrainian].

О. П. Савицкая, Н. В. Савицкая

Львовский институт экономики и туризма, г. Львов, Украина

\title{
ОЦЕНКА УРОВНЯ РИСКА ТУРИСТИЧЕСКОЙ ДЕЯТЕЛЬНОСТИ РЕГИОНОВ УКРАИНЫ СТАТИСТИЧЕСКИМИ МЕТОДАМИ
}

\begin{abstract}
Несмотря на значительное количество публикаций по тематике управления рисками в сфере туристической деятельности, сравнительный анализ научных работ отечественных и зарубежных ученых показал необходимость дальнейшего изучения рисков в сфере туристической деятельности на региональном уровне, с целью учета угроз и опасностей при формировании приоритетных направлений развития регионов, формировании стратегий регионального развития, усилении конкурентоспособности и имиджа как регионов, так и страны в целом и выход на новые международные рынки услуг. Анализ деятельности субъектов туристической деятельности Украины дал возможность выявить негативные тенденции в течение 2013-2015 гг. в их развитии, что свидетельствует о несостоятельности туристических предприятий своевременно реагировать на воздействие факторов внешней и внутренней среды. Оценен уровень и проанализированы риски туристической деятельности регионов Украины статистическим методом путем расчета таких показателей, как среднее значение, дисперсия, стандартное отклонение, коэффициент вариации. Проранжированы регионы Украины по значениям коэффициентов вариации дохода от предоставления туристических услуг, расходов субъектов туристической деятельности на услуги сторонних организаций и загруженности субъектов туристической деятельности.
\end{abstract}

Ключевые слова: туризм; субъекты туристической деятельности; риск; статистический метод оценки рисков; среднее значение; дисперсия; стандартное отклонение; коэффициент вариации; ранжирование регионов.

O. P. Savitska, N. V. Savitska

Lviv Institute of Economy and Tourism, Lviv, Ukraine

\section{RISK LEVEL ASSESSMENT OF TOURIST ACTIVITY OF REGIONS IN UKRAINE BY STATISTICAL METHODS}

Dynamic processes in the development of the world economy combined with the reform of economic relations give the economic complex of Ukraine more and more market features and add to the tourist activity additional elements of uncertainty and risk. Risk research has become particularly relevant in tourism activity, which functioning is closely linked to decision-making in a changing social environment. Therefore, general scientific and special methods were used during the research, in particular: methods of theoretical generalization, comparative analysis of scientific works of domestic and foreign scientists; statistical methods for calculating the indicators of the tourist activity risk level in the regions of Ukraine (average value, variance, standard deviation, coefficient of variation); the ranking method to determine the position of regions in the ranking of the tourism activities risk level. In the course of the research the necessity of further study of risks in the field of tourist activity at the regional level was revealed. The analysis of the indicators of tourist activity in Ukraine allowed revealing negative trends during 2013-2015 in their development, which testifies to the inability of tourist enterprises to respond in a timely manner to the influence of factors of the internal and external environment. In the article the authors evaluate and analyse the level of tourist activity risk in regions of Ukraine by statistical method calculating such indicators as average value, variance, standard deviation, and coefficient of variation. The regions of Ukraine are ranking according to the coefficients of variation of income from the tourist services provision, the expenses of tourist activity to services of thirdparty organizations and the load of tourism activity subjects. The complex of internal and external factors influences tourist activity effectiveness and efficiency. This leads to losses of the tourism company resources, lack of income (profits) or the emergence of additional costs. Preliminary detection of the causes and consequences of possible deviations from the intended purpose will allow responding in a timely manner to negative consequences and developing appropriate measures to counteract the threat of adverse outcome and uncertainty associated with an event. Thus, the results of this study may be useful not only to tourism enterprises, but also local and regional authorities for applying of tourism plans and strategies and the timely response to high risk level in order to neutralize them, as well as for investors in choosing the most effective ways of investing.

Keywords: tourism; subjects of tourist activity; risk; statistical method of risk assessment; average value; variance; standard deviation; variation coefficient; ranking of regions. 